\title{
Prevention and Control of COVID-19 in Chronic Kidney Disease: Correspondence
}

To the Editor: I read with interest the scientific letter by Feng et al. titled 'Prevention and control of COVID-19 in chronic kidney disease' published in Indian Journal of Pediatrics [1] and would like to compliment the authors on their efforts in summarizing their experience in prevention and control of COVID-19 infection in children with chronic kidney disease (CKD).

We would however like to bring to light the following points on the authors' recommendation on discontinuation of use of ACE inhibitors (ACEIs) and angiotensin receptor antagonists (ARBs) in children with CKD with COVID-19 disease based on an animal study [2] cited by them:

1. Many papers published on this aspect have stated that it may be too simplistic to believe that increased expression and activity of ACE- 2 by ARBs may worsen SARSCoronavirus lung injury or Acute kidney injury and some contradicting evidence has been cited which says that they may actually be beneficial $[3,4]$.

2. Also the official statement released by European Society of Hypertension (ESH) and the European Society of Cardiology has clarified that treatment with ACEIs or ARBs should continue in patients with CKD in the same manner except in presence of severe symptoms or hemodynamic instability where their use may be discontinued $[5,6]$.

We therefore request the authors to reconsider their suggestion on discontinuation of ACEIs and ARBs in all children with CKD with COVID-19 disease.

Suprita Kalra

Department of Pediatrics, Army Hospital R\&R, New Delhi, India. E-mail: kalrasuprita@gmail.com

\section{References}

1. Feng S, Xie M, Luo W, et al. Prevention and control of COVID-19 in chronic kidney disease. Indian J Pediatr. 2020. https://doi.org/10. 1007/s12098-020-03306-y.
2. ACE2 expression is induced by treatment with ACE-inhibitors (ACEIs) or angiotensin II AT1 receptor blockers (ARBs) in many rodent tissues. Amino Acids. 2015;47:693-705.

3. Kuba K, Imai Y, Rao S, et al. A crucial role of angiotensin converting enzyme 2 (ACE2) in SARS coronavirus-induced lung injury. Nat Med. 2005;11:875-9.

4. Ye R, Liu Z. ACE2 exhibits protective effects against LPS-induced acute lung injury in mice by inhibiting the LPS-TLR4 pathway. Exp Mol Pathol. 2019;113:104350.

5. ESH Statement on COVID-19. Available at: https://www.eshonline. org/spotlights/esh-statement-on-covid-19/. Accessed 14 May 2020.

6. Position Statement of the ESC Council on Hypertension on ACEInhibitors and Angiotensin Receptor Blockers. Available at: https:// www.escardio.org/Councils/Council-on-Hypertension-(CHT)/News/ position-statement-of-the-esccouncil-on-hypertension-on-aceinhibitorsand-ang. Accessed 14 May 2020.

\section{Author's Reply}

To the Editor: I have read the proposal of Dr. Suprita Kalra carefully. In our article entitled 'Prevention and control of COVID-19 in chronic kidney disease' published in Indian Journal of Pediatrics, we proposed that the pathogenesis of 2019-nCoV is similar to that of SARS virus [1-4], which infects human cells by recognizing and binding to angiotensin converting enzyme (ACE)-2 protein; the use of ACE inhibitors (ACEIs) and angiotensin receptor antagonists (ARBs) can increase the expression and activity of ACE-2 [5]. Therefore, it is suggested that ACEI and ARB should be discontinued in children with COVID-19 and other antihypertensive drugs should be used instead.

Dr. Suprita Kalra has different opinion on the above points, but we think that the points raised by both of us are based on animal experiments, while novel coronavirus is a new virus. We both have just put forward one point of view, which needs to be further confirmed and more studies are needed. 


\section{References}

1. Feng S, Xie M, Luo W, et al. Prevention and control of COVID-19 in chronic kidney disease. Indian J Pediatr. 2020; https://doi.org/10. 1007/s12098-020-03306-y.

2. Zhou P, Yang XL, Wang XG, et al. Discovery of a novel coronavirus associated with the recent pneumonia outbreak in humans and its potential bat origin [J/OL]. bioRxiv. 2020; https://doi.org/10.1101/ 2020.01.22.914952.

3. Xu X, Chen P, Wang J, et al. Evolution of the novel coronavirus from the ongoing Wuhan outbreak and modeling of its spike protein for risk of human transmission [J/OL]. Sci China Life Sci. 2020; https:// doi.org/10.1007/s11427-020-1637-5.

4. Zhao Y, Zhao Z, Wang Y, et al. Single-cell RNA expression profiling of ACE2, the putative receptor of Wuhan 2019-nCoV [J]. bioRxiv. 2020; https://doi.org/10.1101/2020.01.26.919985.

5. ACE2 expression is induced by treatment with ACE-inhibitors (ACEIs) or angiotensin II AT1 receptor blockers (ARBs) in many rodent tissues. Amino Acids. 2015;47:693-705.

Publisher's Note Springer Nature remains neutral with regard to jurisdictional claims in published maps and institutional affiliations. 